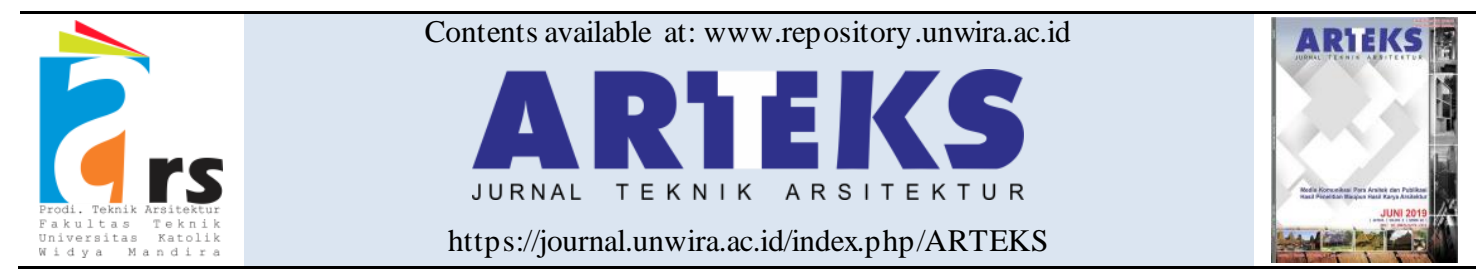

Research paper

doi: 10.30822/arteks.v6i1.584

\title{
The concept of in-between space in Batak Toba vernacular architecture: A content analysis study
}

\author{
Parmonangan Manurung1, 2*何, Diananta Pramitasari ${ }^{3}$ \\ ${ }^{1}$ Department of Architecture, Universitas Kristen Duta Wacana \\ Jl. dr. Wahidin Sudirohusodo, no. 5-25, Yogyakarta, Indonesia \\ ${ }^{2}$ Student of Doctorate Program in Architecture, Faculty of Engineering, \\ Universitas Gadjah Mada, Jl. Grafika, Kec. Mlati, Sleman, D. I. Yogyakarta, Indonesia \\ ${ }^{3}$ Lecturer in Doctorate Program in Architecture, Faculty of Engineering \\ Universitas Gadjah Mada, Jl. Grafika, Kec. Mlati, Sleman, D. I. Yogyakarta, Indonesia
}

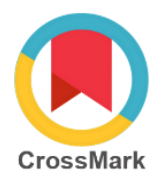

\begin{tabular}{|c|c|}
\hline ARTICLE INFO & ABSTRACT \\
\hline $\begin{array}{l}\text { Article history: } \\
\text { Received June } 22,2020 \\
\text { Received in revised form July } 23,2020 \\
\text { Accepted September } 14,2020 \\
\text { Available online April } 01,2020\end{array}$ & $\begin{array}{l}\text { Space and architecture are two interrelated and encompassing } \\
\text { concepts. However, space has a broad meaning in terms of location, } \\
\text { privacy, and function such that the relationship between two spaces } \\
\text { creates a different atmosphere and impression. A lot of studies have } \\
\text { been conducted on space but there is no much focus on the concept }\end{array}$ \\
\hline $\begin{array}{l}\text { *Corresponding author: Parmonangan } \\
\text { Manurung } \\
\text { Department of Architecture, Universitas } \\
\text { Kristen Duta Wacana, Indonesia } \\
\text { Student of Doctorate Program in Architecture, } \\
\text { Faculty of Engineering, Universitas Gadjah } \\
\text { Mada, Indonesia } \\
\text { Email: monang@staff.ukdw.ac.id; } \\
\text { monang@mail.ugm.ac.id } \\
\text { ORCID: https://orcid.org/ 0000-0003-3983- } \\
\text { 8399 }\end{array}$ & $\begin{array}{l}\text { of 'in-between space'. This research was, therefore, aimed at } \\
\text { exploring in-between space in order to create a clear understanding } \\
\text { and identify its concept in Batak Toba vernacular architecture. A } \\
\text { content analysis method was adopted and this involves analyzing } \\
\text { texts and images related to in-between space and Batak Toba } \\
\text { architecture. The results showed the concept as an overlap created } \\
\text { by two spaces in order to feel the atmosphere of both simultaneously. } \\
\text { It was also discovered not to be a definitive space but found in the } \\
\text { Batak Toba architecture to create a relationship between privacy, } \\
\text { function, and environment. This means it is a key feature of the } \\
\text { architecture and also expected to be a fundamental element in the } \\
\text { modern Toba Batak architecture. These results are expected to serve } \\
\text { as the basis for further in-depth research and to be applied in other } \\
\text { ethnic vernacular architectures. }\end{array}$ \\
\hline
\end{tabular}

\section{Introduction}

The importance of studying in-between spaces

Several national and international scientific publications have been conducted on "space." Space has a physical form, dimensions, location, and observed to be constantly changing and forming memories (Farrelly 2012). It is also defined through some vertical and horizontal elements with due considerations for the conditions needed for proper functioning (Ching 2007). These elements further form clear boundaries to define space and monitor its changes overtime. The concept was also reported to be very important due to its ability to create experience and awareness for users (Wilson 2014). Furthermore, spatialexistence has a strong relationship with the role and position of a unit considered specific to the existence of other 
spaces as well as its ability to attract public attention (Sudaryono 2006).

Space and architecture are interrelated because architecture surrounds space and vice versa towards meeting human needs (Shahlaei and Mohajeri 2015). Built environments are designed according to userneeds (Bielefeld 2018) and this means space is usually planned for a purpose with the intention to accommodate the needs of the users (Namazian and Mehdipour 2013). This, therefore, shows the existence of a strong relationship between the space and users while space quality is closely related to how they perform activities in the space.

Space is often categorized into 'indoor' and 'outdoor' in terms of location such that indoor space refers to the space inside a building while outdoor space focuses on the outside. Meanwhile, it is closely related to control factors such as privacy and territory in terms of design. Territory has a great influence on user privacy and was divided into three levels by Edward T. Hall which are primary, public, and secondary (Namazian and Mehdipour 2013).

Several studies have been conducted on space but those related to in-between space are limited. However, it is possible to interpret the concept of in-between space in several ways with some authors believing it is a space physically existing between two other spaces (Kisho, in Pilgrim 1995; Osorio 2012). It was also as sumed not to be a physical space but a condition in which a user feels the atmosphere of two spaces at the same time (Hertzberger 2005; Vegas et al. 2014).

The background information provided shows there is a knowledge gap to be filled concerning in-between spaces. Studies have, therefore, been conducted on vernacular architecture to sharpen the understanding of this concept due to its deep values and meaning as well as the ability to create a sustainable environment as expressed by Paul Oliver (Dayaratne 2018). On the other hand, the spaces created in the modern era have been separated from the street as outdoor spaces (Can and Heath 2016). Meanwhile, the spaces in vernacular architecture were built by ancestors with inherent meaning and values and this is different from the spaces in modern buildings. Therefore, it is most appropriate to study the in between space for vernacular architecture.

Vernacular buildings around the world provide important lessons needed for sustainable design (Rashid and Ara 2015). Vernacular architecture has also been reported by Scefold to be an interesting and important research object in Indonesia (Manurung 2017). This means its poetic meaning needs to be explored in order to understand its true meaning (Gomez 2006) especially due to the positive goals of the order, meaning, and philosophy passed down to the residents by the ancestors in building vernacular houses (Hatta and Sudrajat 2020).

Batak Toba tribes and architecture

The Toba Batak tribe exists and lives around Lake Toba and Samosir Is land in North Sumatra (Wiryomartono 2020). Moreover, Lake Toba and Batak Toba tribe with their vernacular houses have a long and important historical journey with Lake Toba reported to have been formed by the eruption of Mount Toba about 74,000 years ago (Costa et al. 2014; Blinkhorn et al. 2012). This super eruption released volcanic material reaching South Africa (Smith et al. 2018) and produced a volcanic winter for at least ten years (Robock et al. 2009) which further affect the population and modern human civilization leaving only 3,000 people in the world (Rampino and Ambrose 2000).

The Batak are the third largest ethnic group in Indonesia after Java and Sundanese (Na'im and Syaputra 2012). The Toba Batak tribe inhabits the area around Lake Toba with their territory reported to be covering seven districts in North Sumatra province (Widhijanto and Tisnaningtyas 2018). The existence of this tribe in the interior of the Toba mountains protects its culture from being influenced by others. This makes Batak Toba architecture as well as those related to Toraja in South Sulawesi the most significant vernacular architecture representing Austronesian architecture (Wuisman 2009). These attributes make Batak Toba architecture to be very relevant in studying the concept of in-between space.

Research objectives and problem formulation

The two major purposes of this research were to determine the meaning of in-between spaces using several textual references and images as well as to determine the application of the concept in Batak Toba vernacular architecture. This, therefore, led to the formulation of a research problem which is "what is the meaning of inbetween space and how is it applied in Batak Toba vernacular architecture?" The novel results to be produced are expected to fill the research gaps in the relationship between spaces or in-between 
spaces and also inspire other studies on ethnic vernacular architecture.

\section{Method}

The research was conducted using a content analysis method and this involved a qualitative exploration of the material content (Schreier 2012). This method has several advantages over others (Duriau, Reger, and Pfarrer 2007) due to its ability to cover different theoretical frameworks, methods, and analytical techniques (Denzin and Lincoln 1994; Miles and Huberman 1994 in Duriau, Reger, and Pfarrer 2007).

Content analysis is a scientific tool and research technique used in producing results based on text and other contextual media. It has the ability to help researchers gain new insights and increase their understanding of certain phenomena (Krippendorff 2013). The use of this method has, however, been improved through the rapid development of computer technology (Kelle 1995; Roberts 1997; Tesch 1991; Weitzman and Miles 1995, in Duriau, Reger, and Pfarrer 2007).

\section{Data collection}

The text data were contained in several reference books, journals, proceedings, and dictionaries. They were collected from both online and offline sources and grouped based on the research objectives to contain those related to in-between space as well as those focusing on Batak Toba architecture. Meanwhile, the image and photo data were retrieved from different books, journals, and author documentation and als o classified accordingly for further analysis.

The text and image data were analyzed descriptively and compared to determine the concept of in-between space and its application in Batak Toba vernacular architecture.

\section{Result and discussion}

The texts and photos/images analyzed produced several results related to the in-between space and its application in Batak Toba architecture.

In-between not in between

The definition of the in-between space concept requires understanding the constituent words which are 'in-between' and 'space'. There is, however, a clear difference between 'In between' and 'in-between' with the first defined as being in the middle while the second is a particular thing having the characteristics of two things, for example, "a coat for in-between weather" (Collin s Dictionary n.d.).

The Cambridge Dictionary classifies the word 'in-between' as an adjective which means "between two things that are obvious or accepted, making it difficult to describe or know with certainty." "In-between" also means "having qualities of two different things." These definitions show the word is an adjective describing a noun and also having both qualities, for example, "in-between feeling" which is a combination of two feelings, and "in-between situation" which describes the combination of two situations being experienced or felt (Cambridge Dictionary n.d.).

Space, according to the Cambridge Dictionary, is an empty area which has been used. Aristotle also defined the concept as a "place for something" (Meiss 2013) while Meiss showed it has boundaries on the outside, content on the inside, and emphasizes that all spaces are contained. In terms of the function, Ching (2007) describes space as a medium used in responding to the context and formed by physical elements vertically and horizontally on each side.

In between space: The space between two spaces

The in between space in Japan is known as " $m a "$ and this means an "interval" between spatial or even two or more things. $M a$ is also known as gaps, openings, space in between, time in between, and several others. It also means "relation", "dynamic sense of standing within", "in the middle", and "in between" (Pilgrim 1995). Moreover, Kurokawa Kisho, a contemporary Japanese architect, translated ' $m a$ ' as 'the world in between" and used 'engawa' (beranda) which is part of a traditional Japanese house connecting the outdoor and indoor spaces as well as nature and people with blurred boundaries as an example (Pilgrim 1995).

The beranda is a vertical or horizontal definitive space with a clear scope which serves a way of connecting two spaces, especially the indoor room and the outdoor space. This, therefore, means the definitive space provided by the beranda is between two other different spaces. 
In-between space: Overlapping of two spaces

The in-between space is a concept developed from the threshold by Alison Smithson and Peter Smithson based on a study by photographer Nigel Henderson and sociologist Judith Stephen (Leite 2017). The two architects developed the relationship between the interior and street by expanding the space in 'entering' the public space in order to create social space and a sense of security and comfort. Moreover, Alis on and Peter introduced this new concept as doorstep before it was redefined as in-between (Leite 2017).

Hertzberger has a more basic understanding of the in-between space concept and defined it as "where two worlds overlap" or a place where people feel they are in two worlds at the same time (Hertzberger 2005). It was also explained as a space where a person feels 'inside' and 'outside', both 'private' and 'public', and also has a social contact. It is simply an area where two worlds coexist with the perceived condition depending on the spatial quality of the design presented.

These findings, therefore, showed in-between spaces are not the definitive space between two spaces. It is, therefore, an overlap of two spaces with the quality of both being felt at the same time.

Batak Toba vernacular architecture: An importants study of the in-between space

Space and vernacular architectures are physical forms, and embodiments of cultural values (Koentjaraningrat 2000). Moreover, local cultural values blend with others such as those related to religion to form local wisdom which is manifested in the spatial organization of vernacular settlements (Purbadi, Djunaedi, and Sudaryono 2019). The existence of vernacular architecture is, however, affected by modernization, technological developments, and lifestyle during the developmental stage and this has, therefore, led to its slow replacement by modern buildings (Bański and Wesołowska 2010, in $\mathrm{Li}$ and $\mathrm{Hu}$ 2019) as well and uniform and monotonous architectures (Atik and Erdoğan 2017). The trend has also been discovered in Indonesia (Michiani and Asano 2016) including the Batak Toba architecture (Hanan 2012).

Modern spaces have separated buildings and roads through outdoor spaces, and this was reported to be contrasting to the connectivity created by the traditional city morphology (Can and Heath 2016). The physical changes in vernacular buildings due to modernization, technological developments, and lifestyles (Hanan 2012; Michiani and Asano 2016) are inevitable but their inherent values need to be preserved because they are locality-oriented, sustainable, and applicable in modern buildings (Dayaratne 2018). There is, however, the need to explore these values towards creating localityoriented sustainability. Therefore, the concept of in-between space in vernacular architecture needs to be evaluated for application in modern building designs.

The Batak Toba tribe lives in the huta, a traditional settlement surrounded by a fort (topong ni huta) as high as two to three meters (Siahaan 2005; Setiawan 2010; Hanan 2012). Huta is inhabited by families in one clan, generally consisting of ten houses lined up facing the barn with the founder's house located at the center and designed to be bigger with different ornaments. There is an open space between the house and the barn where traditional ceremonies and daily activities of the villagers take place (Sherman 1990; Sibeth 1991; Siahaan 2005 in Hanan and Meisyara 2017). Figure 1 shows the spatial pattern of the Batak Toba settlement in Huta Siallagan (Siallagan village) where the traditional houses are lined up in an open space orientation facing a row of barns (sopo). The open space is the in-between space which simultaneously provides an atmosphere of a natural and artificial environment.

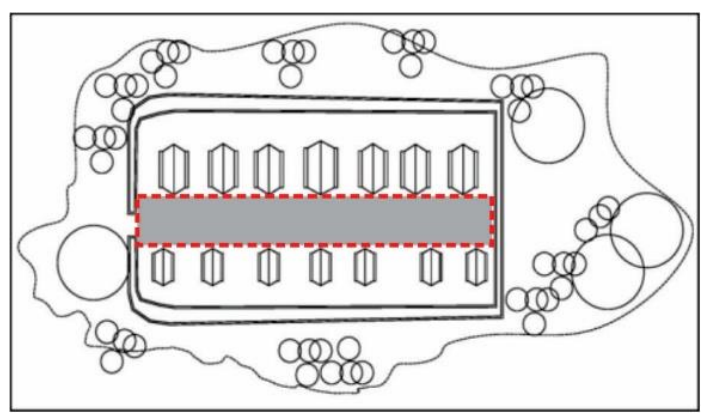

Figure 1. The use of open space as an in-between space between the artificial and natural environment Source: Modified based on Hanan (2012)

The Batak Toba House has two variants, and these include the Sitolumbea with the door on the inside and access to the stairs from below as well as the Sisampur or Sibaba ni amporik with stairs and doors at the front. Apart from these, there is also a Sopo which functions as a granary (Antono 2005; Manurung 2018). The row of Batak Toba Sitolumbea houses in Meat village oriented 
towards the open or public spaces are shown in figure 2 .

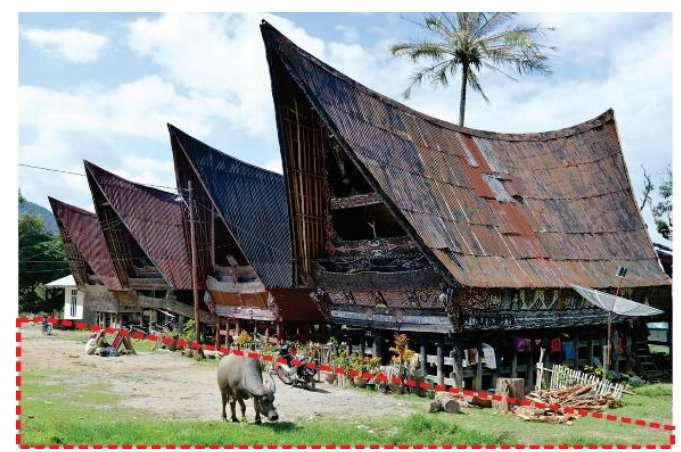

Figure 2. Batak Toba settlement y ard in meat village as in-between space

The Batak Toba architecture is influenced by macrocosmic elements. Vertically, there are three spaces, the roof (banua ginjang/world top), home (banua tonga/middle world), and underneath (banua toru/underworld). The middle world is for the humans, upper for the spirits of their ancestors, and the underworld inhabited by evil spirits and also considered as the world of the dead (Hanan 2012).

The middle world is further divided into several imaginary spaces to represent the open nature of the Batak Toba tribe without any physical barrier. The house functions as their live place and also for traditional ceremonies while each room is designated for a specific person. For example, Jabu tonga is an in-between bedroom for the host and guest as shown in figure 3 while Jabu bona as a place to receive gifts during the ceremony as well as the parents' bedroom. Moreover, Jabu tamparpiring is designed for the hula-hula (wife-giver party) and the youngest sibling of the same clan (dongan sabutuha/similar clan) while Jabu soding is the venue for the ceremony as well as the daughter's bed. Meanwhile, Jabu suhat is for the boru (wife taker) during the ceremony and the boys' bed while a kitchen, in the form of a stove, is also located in the Jabu tonga-tonga which is the living room (Napitupulu et al. 1997; Wiryomartono 2020).

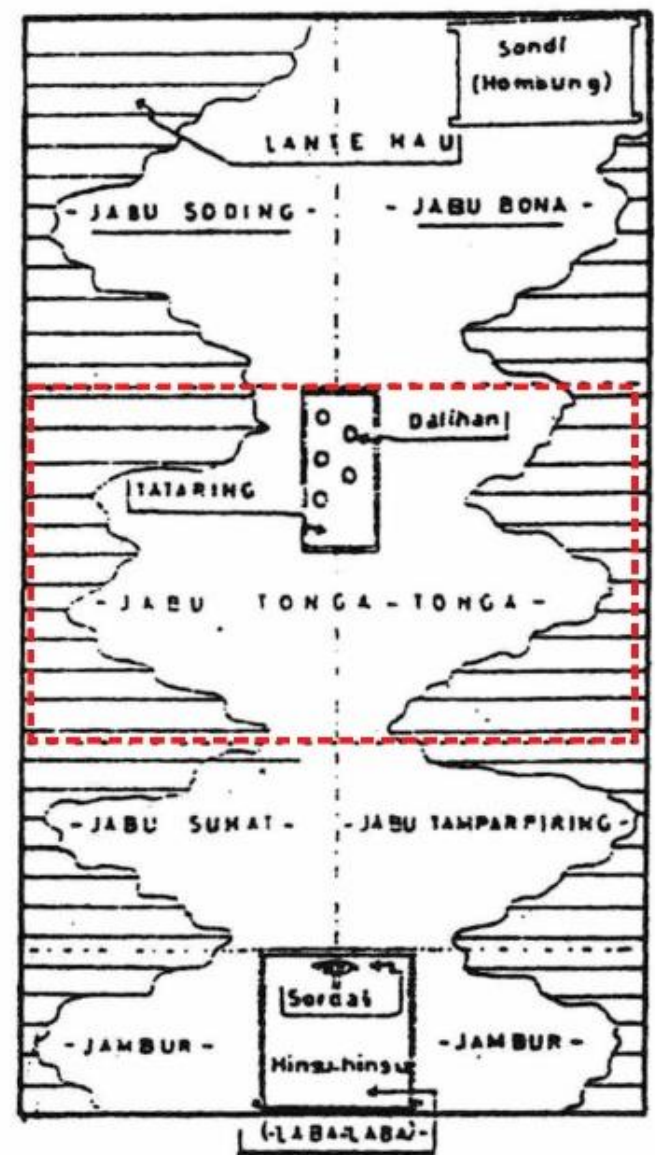

Figure 3. One of the in-between spaces in the room of Batak Toba house

Source: Modified based on Napitupulu et al. (1997)

The in-between space is not only formed based on the relationship between outdoor and indoor spaces, but these spaces are considered as an element. There are other atmospheres and these include inside and outside while Vegas et al. (2014) reported the formation of a relationship between two other elements which are area including private and public, function including shop and home, media including water and land, and environment including artificial and natural as well as several others (Vegas et al. 2014). These, therefore, showed the importance of studying the Batak Toba architecture in evaluating the concept of in-between space.

In-between space not in between space

The findings differentiated in-between and in between as two different concepts of space. In between space was defined as a space serving as the transition between two others while in- 
between space is the overlapping of two adjacent spaces with the atmosphere of both felt simultaneously.

Newman also classified territorial space into four levels which are private, semi-private, semipublic, and public (Huang, Mori, and Nomura 2019). The in between space was observed to be formed between public and private areas due to its manifestation as a definitive space used in transiting (Vegas et al. 2014) while the semiprivate or semi-public space serves as an inbetween space.

The relationship between two media, according to Vegas, creates an in-between space due to the interaction between two areas and functions (Vegas et al. 2014). Vegas further used land and water as an example and their ability to create in-between spaces.

Natural and artificial environments are among the elements creating in-between space (Vegas et al. 2014) and this is manifested in the intersection between buildings and the natural environment. This is experienced by a person in an environment but having a feeling of two atmospheres.

In-between space is also created from the relationship between indoor and outdoor space by bringing and creating an ambiguous experience for each character (Shahlaei and Mohajeri 2015). The space provides benefits due to the feelings of both spaces simultaneously experienced by an individual, but its existence is highly dependent on several factors such as architectural functions, climate, lifestyle, aesthetics to be achieved, and others.

Indoor space protects humans from nature and climate and also provides comfort while outdoor space aids the interaction with nature and the in between space is the accommodation of these functions in a place (Osorio 2012; Shahlaei and Mohajeri 2015). This is important considering the difference in outdoor and indoor space in terms of both natural environment and roads (Can and Heath 2016; Shahlaei and Mohajeri 2015).

Vegas et al. also showed the relationship between two building functions create an inbetween space as observed with a house and a shop. For example, a row of horizontal or vertical buildings with the bottom or front part used as a shop while the back or upper floor is a residence is referred to as a 'ruko' or shop-house and this has been reported to be influenced by the existence of Chinatowns and Chinese architecture (Yulianto 2005, and Asih 2007 in D. Setiawan and Utami 2016; Khatimah 2013).
The in-between space was observed to have been created by this structure according to Vegas et al. The residence or house is placed at the back or top side while the commercial aspect or shop is at the front/bottom and closely related to the nature of the space. The door or stairs connecting the shophouse provides a space to experience the two different functions which include accessing the house or the private area as well as the shop or the public area. This means the in-between space role is being played by the doors and stairs as shown in figure 4.

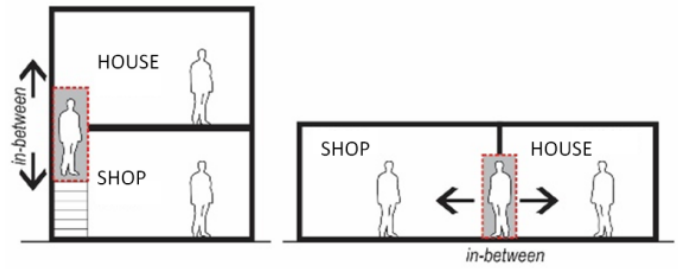

Figure 4. Stairs and shop doors are in-between space Source: Modified based on Vegas et al. (2014), D. Setiawan and Utami (2016), and Khatimah (2013).

It is also possible to present the in-between space through the threshold indicated in figure 5a. Threshold was argued by Hertzberger to be an extension of interior space presented through an additional roof or seat in front of the house. It provides residents access to indoor experiences such as telephone sounds and others when they simultaneously being connected to the outside world. This means the residents feel both inside and outside the house and also have a sense of security and comfort by being in their territory (Hertzberger 2005).

According to Hertzberger, a threshold can be created with a dutch door type as shown in Figure 5b. with two parts, top and bottom, which makes it possible to be closed, partially opened, or completely opened.

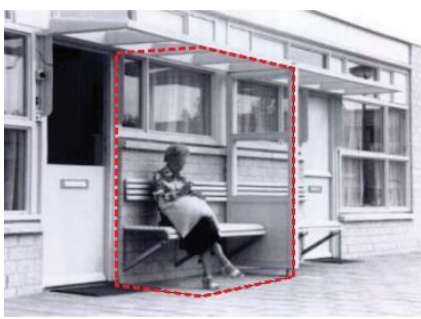

(a)

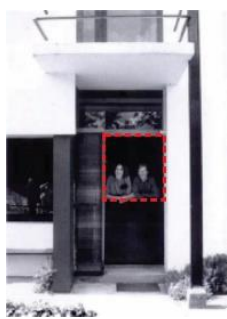

(b)
Figure 5. Threshold and Dutch door are in-between space

Source: (Hertzberger 2005) 
Dutch doors create both privacy and connection with people outside the home and also used in the bathroom of nursing homes for nurses to monitor the condition of elderlies in the bathroom and activities in the other rooms (Parmonangan 2016).

Several findings also showed the clear difference between the "in-between" and "in between" spaces with the first defined as the perceived quality of two different spaces and a mechanism to reduce sharp differences in the spaces. It is useful in feeling the transitions and impression of two different spaces simultaneously. Meanwhile, in between space is just a definitive space between two spaces.

An in-between space in Batak Toba vernacular architecture

The concept of in-between space was found in the outdoor and indoor space of Batak Toba house as observed with the use of beranda (banua tonga) to explain the relationship between two environments involving the artificial such as house or forest and the natural environment such as mountains and lakes as well as two media including land and water. It also indicates the concept of in-between space within two different worlds which are the banua ginjang and banua toru.

The in-between space within the indoor or private and outdoor or public spaces is reflected by the balcony as shown in figure 6 . This is due to its ability to allow the feeling of the atmosphere in the two spaces as shown by the Hertzberger (2005) concept in figure 7.
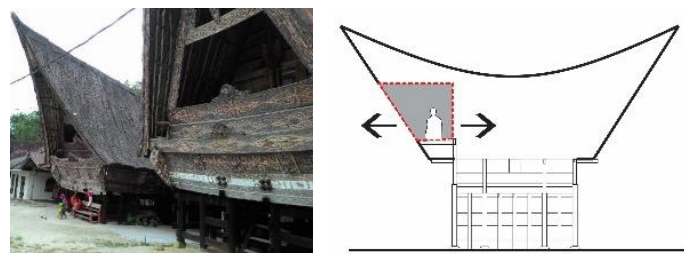

Figure 6. Balcony between the indoor and outdoor spaces

The relationship between outdoor or public and indoor or private is also felt through small windows on the left and right sides of the house. These windows have a sloping wall which makes it easy for residents inside the house to have visual contact and communicate with people outside while maintaining their privacy.

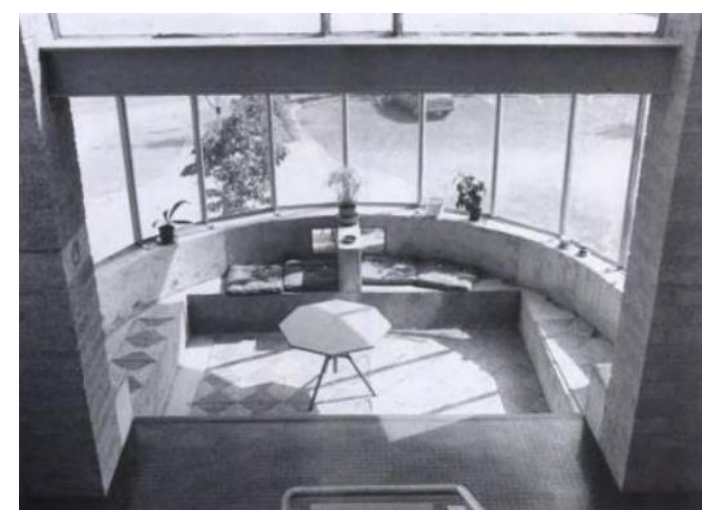

Figure 7. The in-between Hertzberger concept Source: (Hertzberger 2005)

The in-between space as a combination of two functions is also indicated in the function of the cattle cage under the house (banua toru), and the location of the house (banua tonga) at the top. The stairs act as an in-between space by allowing the simultaneous feeling of the atmosphere created by two different functions.

The in-between space is strongly formed indoor due to the non-definitive definition of each space $(j a b u)$. The Batak Toba tribe, however, knows the position and status of each area when the house is used for both residential and ceremonial purposes. Moreover, the in-between space is felt in one room or jabu as shown in figure 3 due to the simultaneous existence of the atmosphere created by two different rooms. The other areas where the concept was discovered are presented in the following table 1.

Table 1. Identification of the in-between spaces in the Toba Batak architecture

\begin{tabular}{ll}
\hline $\begin{array}{l}\text { Space in Toba Batak } \\
\text { Vernacular } \\
\text { Architecture }\end{array}$ & In-between concept \\
\hline - Huta (village) & • $\begin{array}{l}\text { Between the two media } \\
\text { (land and water) }\end{array}$ \\
- Outdoor & - $\begin{array}{l}\text { Between two environments } \\
\text { (natural and artificial) }\end{array}$ \\
- Home/central & - Between the two functions \\
world/banua tonga & upper world and \\
& underworld) \\
- Balcony & Between two areas (public \\
& and private) \\
- Stairs & Between two functions \\
- Doors \& windows & Between public and private \\
- Jabu & Between two different \\
&
\end{tabular}

The findings and discussion showed the difference in the meanings of in-between and in between spaces. The application and importance 
of in-between space to the Batak Toba vernacular architecture were also highlighted. The results have, therefore, contributed to the filling of the research gaps discovered in the meaning and concept of in-between space and also serve as an inspiration for future studies using other ethnic vernacular architectures.

\section{Conclusion}

There are differences in the meanings of inbetween and in between with the first discovered not be a definitive space but a condition when a person feels the atmosphere of two spaces simultaneously. The concept was further discovered in Batak Toba vernacular architecture to be a key feature and fundamental element to be introduced to modern design related to the culture. These results serve as an inspiration for further research to be conducted on other ethnic vernacular architectures.

\section{Acknowledgment}

The author is grateful to the Doctorate Program in Architecture, Faculty of Engineering, Universitas Gadjah Mada; Department of Architecture, Universitas Kristen Duta Wacana; and the Educational Fund Management Institution (LPDP) for all the support provided during the writing process.

\section{References}

Antono, Yustinus Slamet. 2005. 'Rumah Tradisional Batak Toba Menuju Kepunahan: Suatu Analisis Antropologis'. Logos 4 (2): 107-33. http://ejournal.ust.ac.id/index.php/LOGOS/ar ticle/view/397.

Atik, Damla, and Nevnihal Erdoğan. 2017. 'A Model Suggestion for Determining Physical and Socio-Cultural Changes of Traditional Settlements in Turkey'. A/Z: ITU Journal of
Faculty of Architecture 14 (2): 81-93. https://doi.org/10.5505/itujfa.2017.62534.

Bielefeld, Bert. 2018. Spaces in Architecture: Areas, Distances, Dimensions. Basel: Birkhauser-Publisher for Architecture.

Blinkhorn, J., A.G. Parker, P. Ditchfield, M. Haslam, and M. Petraglia. 2012. 'Uncovering a Landscape Buried by the Super-Eruption of Toba, 74,000 Years Ago: A Multi-Proxy Environmental Reconstruction of Landscape Heterogeneity in the Jurreru Valley, South India'. Quaternary International 258 (May): 135-47. https://doi.org/10.1016/j.quaint.2011.12.008.

Cambridge Dictionary. n.d. 'Meaning of Inbetween in English'. Cambridge. Accessed 20 February 2020. https://dictionary.cambridge.org/dictionary/e nglish/in-between.

Can, Işın, and Tim Heath. 2016. 'In-between Spaces and Social Interaction: A Morphological Analys is of Izmir Using Space Syntax'. Journal of Housing and the Built Environment $31 \quad$ (1): 31-49. https://doi.org/10.1007/s 10901-015-9442-9.

Ching, Francis D. K. 2007. Architecture: Form, Space, and Order. 3rd ed. New Jersey: John Wiley \& Sons, Inc.

Collins Dictionary. n.d. 'Definition of 'in Between'. Collins. Accessed 20 February 2020.

https://www.collins dictionary.com/dictionary /english/in-between.

Costa, Antonio, Victoria C. Smith, Giovanni Macedonio, and Naomi E. Matthews. 2014. 'The Magnitude and Impact of the Youngest Toba Tuff Super-Eruption'. Frontiers in Earth Science 2 (August). https://doi.org/10.3389/feart.2014.00016.

Dayaratne, Ranjith. 2018. 'Toward Sustainable Development: Lessons from Vernacular Settlements of Sri Lanka'. Frontiers of Architectural Research 7 (3): 334-46. https://doi.org/10.1016/j.foar.2018.04.002.

Duriau, Vincent J., Rhonda K. Reger, and Michael D. Pfarrer. 2007. 'A Content Analysis of the Content Analysis Literature in Organization Studies: Research Themes, Data Sources, and Methodological Refinements'. Organizational Research Methods 10 (1): 5- 
34.

https://doi.org/10.1177/1094428106289252.

Farrelly, Lorraine. 2012. The Fundamentals of Architecture. 2nd ed. Switzerland: AVA Publishing SA.

Gomez, Alberto Perez. 2006. 'The Space of Architecture: Meaning as Presence and Presentation'. In Questions of Perception: Phenomenology of Architecture, edited by Steven Holl, Juhani Pallasmaa, and Alberto Perez Gomez, 2nd ed., 7-25. San Francisco: William Stout Publishers.

Hanan, Himasari. 2012. 'Modernization and Cultural Transformation: The Expansion of Traditional Batak Toba House in Huta Siallagan'. Procedia - Social and Behavioral Sciences 50:

$800-811$. https://doi.org/10.1016/j.sbspro.2012.08.082.

Hanan, Himasari, and Fitri Meisyara. 2017. 'Lesson Learned from the Transformation Process of Toba Batak Villages Meisyara Lesson Learned from the Transformation Process of Toba Batak Villages'. Journal of Comparative Cultural Studies in Architecture 10: 35-41.

Hatta, Asta Juliarman, and Iwan Sudrajat. 2020. 'Peran Sanro Bola Dalam Tradisi Membangun Rumah Tradisional Bugis Di Kabupaten Soppeng'. ARTEKS : Jurnal Teknik Arsitektur 5 (1): 57-66. https://doi.org/10.30822/arteks.v5i1.119.

Hertzberger, Herman. 2005. Lessons for Students in Architecture. Rotterdam: 010 Publisher.

Huang, Jiayu, Suguru Mori, and Rie Nomura. 2019. 'Territorial Cognition, Behavior, and Space of Residents: A Comparative Study of Territoriality between Open and Gated Housing Blocks; a Case Study of Changchun, China'. Sustainability 11 (8): 2332. https://doi.org/10.3390/su11082332.

Khatimah, Husnul. 2013. 'Kajian Kesesuaian Pembangunan Ruko Terhadap Kebutuhan Pasar Di Kota Mataram'. JURNAL PEMBANGUNAN WILAYAH \& KOTA 9 (3): 271. https://doi.org/10.14710/pwk.v9i3.6539.

Koentjaraningrat. 2000. Kebudayaan, Mentalitas Dan Pembangunan. Jakarta: Gramedia Pustaka Utama.

Krippendorff, Klaus. 2013. Content Analysis: An Introduction to Its Methodology. 3rd ed. California: SAGE.

Leite, Bárbara. 2017. 'Threshold and Mediation Devices in the Domestic Space Approach'. In Utopia(s) - Worlds and Frontiers of the
Imaginary, edited by Maria do Rosário Monteiro, Mário S. Ming Kong, and Maria João Pereira Neto, 83-86. London: CRS Press, Taylor \& Franis Group.

Li, Guo, and Wenmin Hu. 2019. 'A NetworkBased Approach for Landscape Integration of Traditional Settlements: A Case Study in the Wuling Mountain Area, Southwestern China'. Land Use Policy 83 (April): 105-12. https://doi.org/10.1016/j.landusepol.2019.01. 043.

Manurung, Parmonangan. 2016. 'Considering the Elderly'S Needs in Developing Nursing Home Design'. DIMENSI (Journal of Architecture and Built Environment) 43 (1). https://doi.org/10.9744/dimensi.43.1.9-14.

2017. 'Daylighting and Architectural Concept of Traditional Architecture: The Tongkonan in Toraja, Indonesia'. A/Z: ITU Journal of Faculty of Architecture 14 (1): $111-26$. https://doi.org/10.5505/itujfa.2017.65487.

- 2018. 'Dampak Pelestarian Arsitektur Tradisional Terhadap Pengembangan Desa Wisata'. In Simposium Nasional RAPI XVII2018 FT UMS, 9-13. Surakarta: Universitas Muhammadiyah Surakarta. https://publikasiilmiah.ums.ac.id/bitstream/ha ndle/11617/10618/paper_A_06.pdf?sequence $=1$ \&is Allowed $=\mathrm{y}$.

Meiss, Pierre von. 2013. Elements of Architecture: From Form to Place + Tectonics. 2nd ed. Lausanne: EPFL Press.

Michiani, Meidwinna Vania, and Junichiro Asano. 2016. 'Influence of Inhabitant Background on the Physical Changes of Banjarese Houses: A Case Study in Kuin Utara Settlement, Banjarmasin, Indonesia'. Frontiers of Architectural Research 5 (4): 412-24. https://doi.org/10.1016/j.foar.2016.09.005.

Na'im, Akhsan, and Hendry Syaputra. 2012. Kewarganegaraan, Suku Bangsa, Agama, Dan Bahasa Sehari-Hari Penduduk Indonesia: Hasil Sensus Penduduk 2010. Jakarta: Badan Pusat Statistik. https://www.bps.go.id/publication/2012/05/2 3/55eca38b7fe0830834605b 35/kewarganegar aan-suku-bangsa-agama-dan-bahasa-seharihari-penduduk-indonesia.htm.

Namazian, Ali, and Armin Mehdipour. 2013. 'Psychological Demands of the Built Environment, Privacy, Personal Space and Territory in Architecture'. International 
Journal of Psychology and Behavioral Sciences $\quad 3 \quad$ (4): $109-13$. https://doi.org/10.5923/j.ijpbs.20130304.04.

Napitupulu, S. P., Jintar Manurung, Mardyan Ginting, H. Sirait, and T. Silalahi. 1997. Arsitektur Tradisional Daerah Sumatera Utara. Jakarta: Departemen Pendidikan dan Kebudayaan RI.

Osorio, Emil. 2012. 'In-Between Spaces in Antofagasta: Relationship of Architecture with its Context'. AUS, no. 12: 10-13. https://doi.org/10.4206/aus.2012.n12-03.

Pilgrim, Richard B. 1995. 'Intervals (Ma) in Space and Time: Foundations for a Religio Aesthetic Paradigm in Japan'. In Japan in Traditional and Postmodern Perspectives, edited by Charles Wei-hsun Fu and Steven Heine, 55-80. Albany: State University of New York Press.

Purbadi, Yohanes Djarot, Achmad Djunaedi, and Sudaryono. 2019. 'Kearifan Kaenbaun Sebagai Dasar Konseptual Pada Tata Spasial Arsitektur Permukiman Suku Dawan Di Desa Kaenbaun'. ARTEKS: Jurnal Teknik Arsitektur 3 (2): $215-38$. https://doi.org/10.30822/arteks.v3i2.71.

Rampino, Michael R., and Stanley H. Ambrose. 2000. 'Volcanic Winter in the Garden of Eden: The Toba Supereruption and the Late Pleistocene Human Population Crash'. In Volcanic Hazards and Disasters in Human Antiquity. Geological Society of America. https://doi.org/10.1130/0-8137-2345-0.71.

Rashid, Mamun, and Dilshad Rahat Ara. 2015. 'Modernity in Tradition: Reflections on Building Design and Technology in the Asian Vernacular'. Frontiers of Architectural Research 4 (1): 46-55. https://doi.org/10.1016/j.foar.2014.11.001.

Robock, Alan, Caspar M. Ammann, Luke Oman, Drew Shindell, Samuel Levis, and Georgiy Stenchikov. 2009. 'Did the Toba Volcanic Eruption of $\sim 74$ Ka B.P. Produce Widespread Glaciation?' Journal of Geophysical Research 114 (D10): D10107. https://doi.org/10.1029/2008JD011652.

Schreier, Margrit. 2012. Qualitative Content Analysis in Practice. London: SAGE Publications, Ltd.

Setiawan, Dedi, and Tin Budi Utami. 2016. 'Tipologi Perubahan Elemen Fasad Bangunan Ruko Pada Penggal Jalan Puri Indah, Jakarta Barat'. Vitruvian: Jurnal Arsitektur, Bangunan, Dan Lingkungan 6 (1): 15-24. https://publikasi.mercubuana.ac.id/index.php/ virtuvian/article/view/975/756.

Setiawan, Taufiqurrahman. 2010. 'Bentuk Adaptasi Lingkungan Pada Permukiman Tradisional Di Danau Toba'. Berkala Arkeologi Sangkhakala 13 (25): 145-53. https://doi.org/https://doi.org/10.24832/bas.v 13i25.196.

Shahlaei, Alireza, and Marzieh Mohajeri. 2015. 'In-Between Space, Dialectic of Inside and Outside in Architecture'. International Journal of Architecture and Urban Development 5 (3): 73-80. https://ijaud.srbiau.ac.ir/article_8548.html.

Siahaan, Bisuk. 2005. Batak Toba: Kehidupan Di Balik Tembok Bambu. Jakarta: Kempala Foundation.

Smith, Eugene I., Zenobia Jacobs, Racheal Johnsen, Minghua Ren, Erich C. Fisher, Simen Oestmo, Jayne Wilkins, et al. 2018. 'Humans Thrived in South Africa through the Toba Eruption about 74,000 Years Ago'. Nature $555 \quad$ (7697): $511-15$. https://doi.org/10.1038/nature25967.

Sudaryono. 2006. 'Paradigma Lokalisme Dalam Perencanaan Spasial'. Journal of Regional and City Planning 17 (1): 28-38. https ://journals .itb.ac.id/index.php/jpwk/articl e/view/4232.

Vegas, Fernando, Camilla Mileto, Juan Maria Songel, and Juan Fco. Noguera. 2014. 'InBetween Spaces, Borderline Places'. In Versus: Heritage for Tomorrow, Vernacular Knowledge for Sustainable Architecture, edited by Mariana Correia, Letizia Dipasquale, and Saverio Mecca, 188-200. Firenze: Firenze University Press.

Widhijanto, Andreas Agung, and Esti Yulitriani Tisnaningtyas. 2018. 'Identifikasi Kawasan Permukiman Pendukung - Analis is Proximity Pengembangan Destinasi Wisata Danau Toba'. Neo Teknika : Jurnal Ilmiah Teknologi 4 (1): 11-19. http://jurnal.unpand.ac.id/index.php/NT/articl e/view/1062/1037.

Wilson, Colin St John. 2014. Architectural Reflections: Studies in the Philosophy and Practice of Architecture. Oxford, England: Butterworth Architecture.

Wiryomartono, Bagoes. 2020. Traditions and Transformations of Habitation in Indonesia 
Power, Architecture, and Urbanism. Bangunan Masa Lalu Dan Masa Kini'. In Singapore: Springer.

Wuisman, Jan. J. J. M. 2009. 'Masa Lalu Dan

Masa Kini: Posisi Dan Peran Tradisi-Tradis i

Vernakular Indonesia Dan Langgam

Masa Lalu Dalam Masa Kini Arsitektur Di Indonesia, edited by Peter J. M. Nas, 25-47. Jakarta: PT. Gramedia Pustaka Utama. 
ARTEKS : Jurnal Teknik Arsitektur, Volume 6 Issue 1, April 2021

pISSN2541-0598; eISSN2541-1217 